\title{
Rediscovery of the endemic gastropod Dianella schlickumi (Gastropoda, Hydrobiidae) and its discrimination from Dianella thiesseana: environmental correlates and implications for their conservation
}

\author{
Chrysoula Ntislidou ${ }^{1,2}$, Canella Radea ${ }^{3}$, Sinos Giokas ${ }^{4}$, Martin T. Pusch², \\ Maria Lazaridou', Dimitra C. Bobori'
}

I Department of Zoology, School of Biology, Aristotle University of Thessaloniki, 54124 Thessaloniki, Greece 2 Leibniz Institute of Freshwater Ecology and Inland Fisheries (IGB), 12587 Berlin, Germany 3 Department of Ecology and Systematics, Faculty of Biology, School of Sciences, National and Kapodistrian University of Athens, 15784, Panepistimioupolis, Greece 4 Department of Biology, University of Patras, 26500, Patra, Greece

Corresponding author: Chrysoula Ntislidou (ntislidou@bio.auth.gr)

Academic editor: M. Pinna | Received 7 January 2018 | Accepted 24 May 2018 | Published 11 June 2018

http://zoobank.org/EF862219-884C-436F-BF54-7603F97EEFFB

Citation: Ntislidou C, Radea C, Giokas S, Pusch MT, Lazaridou M, Bobori DC (2018) Rediscovery of the endemic gastropod Dianella schlickumi (Gastropoda, Hydrobiidae) and its discrimination from Dianella thiesseana: environmental correlates and implications for their conservation. Nature Conservation 27: 35-58. https://doi.org/10.3897/ natureconservation.27.23289

\begin{abstract}
The aquatic snail genus Dianella (Gastropoda: Hydrobiidae) has only two representatives in Greece: $D i$ anella schlickumi Schütt, 1962 and Dianella thiesseana (Kobelt, 1878). D. schlickumi, a narrow endemic species to Lake Amvrakia (in Aitoloakarnania, western-central Greece), is considered as Critically Endangered (Possibly Extinct, sensu IUCN 2017). Our study confirmed its presence in Lake Amvrakia, where it had not been detected for more than 30 years. We document the unknown anatomical characters based on the D. schlickumi specimens. Moreover, the presence of D. thiesseana in the nearby lakes Trichonis and Lysimachia was also confirmed, while morphometric analyses enabled the discrimination between the two species. Redundancy Analysis revealed conductivity, dissolved oxygen and $\mathrm{pH}$ as the main environmental variables related to the above species' distribution, shaping their community structure. Both Dianella species require urgent conservation measures to be enforced, due to their habitat degradation from human activities, which are limiting and fragmenting their range. For that purpose, effective management plans have to be elaborated and implemented at the mentioned lakes, focusing on the reduction of human pressures and on the improvement of their habitats.
\end{abstract}

Copyright Chrysoula Ntislidou et al. This is an open access article distributed under the terms of the Creative Commons Attribution License (CC BY 4.0), which permits unrestricted use, distribution, and reproduction in any medium, provided the original author and source are credited. 


\section{Keywords}

Pyrgulinid, Greek lakes, anatomy, morphometrics, environmental correlates, conservation

\section{Introduction}

Freshwater habitats cover less than $1 \%$ of the earth's surface, but they support almost $10 \%$ of the known species on the planet (Strayer and Dudgeon 2010). However, freshwater species are in a worldwide decline (Howard et al. 2015), resulting thus in the decrease of freshwater biodiversity, which is mainly threatened by over-exploitation, water pollution, hydrological alterations, destruction and degradation of habitats and invasion by exotic species (Dudgeon et al. 2006).

The Balkan region is rich in freshwater fauna due to high endemism (Griffith et al. 2004, Glöer et al. 2007). The rich fauna of freshwater molluscs is considerably threatened (Albrecht and Wilke 2008) and 29 species of the Balkan Peninsula have already become extinct (Régnier et al. 2009), representing 21\% of the 140 known extinctions of freshwater mollusc species worldwide. In this region, many endemic gastropod species exist with a restricted range only extending to small hydrographic systems (rivers, lakes and springs). The karst landscape, which occurs in a large proportion of the Balkan Peninsula, also contributes to this high degree of endemism (Régnier et al. 2009). These species are vulnerable not only due to habitat degradation caused by human activities, but also by their very limited range, which increases the risk of accidental extinction (Régnier et al. 2009). For Greece, a similar crucial decline of population densities and losses of some endemic mollusc species have been reported (Albrecht et al. 2006), suggesting the necessity for urgent actions for their conservation.

The distribution of gastropod species is often associated with biotic and abiotic habitat parameters (e.g. Covich 2010), which are related to specific geographical characteristics, physicochemical conditions, biological interactions and historical and random factors (Lodge et al. 1987). Thus, the distributional patterns of endemics can be often better explained based on records of key environmental parameters, which drive the structure of biological communities (Pérez-Quintero 2012). Such knowledge may also help to identify and protect specific regions for the conservation of biodiversity of little-known freshwater bodies (Abell et al. 2007), especially in the Mediterranean region which has been neglected.

The species of the subfamily Pyrgulinae (Caenogastropoda: Truncatelloidea: Hydrobiidae) are widely distributed in western Asia as well as in central and south-eastern Europe (Wilke et al. 2007). In the latter area, the subfamily consists of ten genera, namely Chilopyrgula Brusina, 1896, Dianella Gude, 1913, Ginaia Brusina, 1896, Neofossarulus Polinski, 1929, Ochridopyrgula Radoman, 1955, Pyrgohydrobia Radoman, 1955, Pyrgula De Cristofori \& Jan, 1832, Stankovicia Polinski 1929, Trachyochridia Polinski, 1929 and Xestopyrgula Polinski, 1929, comprising 17 species (Bank 2017). 
The pyrgulinids are mostly lacustrine snails, colonising the littoral and sublittoral zones of ancient deep freshwater lakes (Radoman 1983, Wilke et al. 2007, Schreiber et al. 2012). Only one species, Chilopyrgula sturanyi Brusina, 1896, has been recorded in springs (Radoman 1983).

Out of those, two pyrgulinid species, belonging to the genus Dianella Gude, 1913, are known to be present in lentic systems of Greece: Dianella schlickumi Schütt, 1962 and Dianella thiesseana (Kobelt, 1878). The first species is known from Lake Amvrakia and the latter from lakes Trichonis and Lysimachia (Aitoloakarnania, western-central Greece) (Schütt 1962, Radoman 1973, 1983, Szarowska et al. 2005, Szarowska 2006). Both species are narrow endemic species, with major gaps in historical records, while no information is available about their abundance, population structure, life cycle or genetic diversity. In the IUCN Red List of Threatened Species, Dianella thiesseana appears under the status "Critically Endangered", while D. schlickumi has been declared as "Possibly Extinct" (IUCN 2017). Apart from Dianella, the aquatic gastropod communities of these lakes include several other endemic hydrobiids, such as Islamia graeca Radoman, 1973, Islamia trichoniana Radoman, 1979, Pseudoislamia balcanica Radoman, 1979, Trichonia trichonica Radoman, 1973 (Radoman 1983). D. schlickumi has not been observed for more than 30 years, despite several sampling efforts performed in Lake Amvrakia (Reischütz and Reischütz 2002, Szarowska et al. 2005, Albrecht et al. 2006, 2011a), which is considered as the type locality of this species. Only fresh empty shells of this species were recorded in an irrigation channel, near Acheloos River (close to Lake Amvrakia) by Reischütz et al. (2008). D. thiesseana has only been found at the northeast bank of Lake Trichonis during the last decade (Albrecht et al. 2009, 2011b).

The external morphology, the anatomy and the phylogenetic position of the majority of Pyrgulinae have been extensively studied and discussed (Schütt 1962, Radoman 1983, Riedel et al. 2001, Szarowska et al. 2005, Szarowska 2006, Anistratenko 2008, Wilke et al. 2013). The combination of anatomical and phylogenetic data suggests that the Pyrgulinae subfamily has a very close (possibly even sistergroup) systematic relationship with Hydrobiinae (Szarowska et al. 2005). Concerning the two species of Dianella, it has been reported that they have similar external morphology and soft body anatomy, but different body size (Radoman 1983). However, the inter-specific differences have been questioned by Szarowska et al. (2005), which has made the taxonomic distinction between $D$. thiesseana and $D$. schlickumi unclear and questionable. Although the soft body anatomy of $D$. thiesseana is described and/or depicted in detail (Radoman 1983, Szarowska et al. 2005, Szarowska 2006), various anatomical characters of D. schlickumi remain unknown, un-described or unpublished.

Hence, the aims of the present study were to: (a) report the rediscovery of the seemingly extinct pyrgulinid $D$. schlickumi, (b) describe its unknown anatomical characters, (c) examine its morphometric discrimination from D. thiesseana and (d) reveal the environmental parameters that probably drive the distribution of both species. 


\section{Material and methods}

\section{Study area}

We studied three natural lakes located in the western-central part of Greece (Figure 1). These lakes are considered as the last remains of a former big lake, which by several processes, has been split into four smaller lakes (Albanakis et al. 1995). The Acheloos River separates Amvrakia and Ozeros lakes from Trichonis and Lysimachia lakes (Figure 1). Lake Amvrakia (Table 1) is a semipolje karst lake of tectonic origin with high sulphate concentrations, situated in Mesozoic limestone (Verginis and Leontaris 1978, Overbeck et al. 1982). Its water level shows significant seasonal fluctuations, which may be attributed to various factors such as the hydraulic communication with karst aquifers, high evaporation rates, especially during summer and intensive use of water for agricultural purposes (Danielidis et al. 1996). Lake Trichonis (Table 1) is the deepest and the largest natural lake in Greece, which is also a karst water body (Zacharias et al. 2002), situated in a tectonically active area (Poulimenos and Doutsos 1997). It is supplied by precipitation, approximately 30 intermittent streams and sub-aquatic karst springs (Dimitriou and Zacharias 2006). At its western end, a narrow canal connects Lake Trichonis with Lake Lysimachia (Table 1), which is shallower (Figure 1) and it was receiving the untreated urban wastewaters from the city of Agrinio until the year 2000. At its western end, Lake Lysimachia drains to the Acheloos River via an artificial canal (Figure 1).

\section{Field sampling}

Macroinvertebrate samplings were conducted in spring and autumn 2014 by boat, at the sublittoral and profundal zones of each lake, using an Ekman-Birge grab (three replicates per station, $225 \mathrm{~cm}^{2}$ sampling area). A total of 66 samples were collected in the studied lakes [Amvrakia: 14 stations (7 stations at each zone), Trichonis: 13 (5 and 7 stations at the sublittoral and profundal zones, respectively) and Lysimachia: 6 (3 stations at each zone); Figure 1]. Samples were sieved with a $500 \mu \mathrm{m}$ mesh and preserved

Table I. Geographical position, morphological and limnological features of the studied lakes. Alt: altitude; $Z_{\text {mean }}$ : mean depth; $Z_{\max }$ : max depth; $L_{a}$ : lake surface area; TL: trophic level, ET: eutrophic, MT: mesotrophic, OL: oligotrophic; WMM: warm monomictic.

\begin{tabular}{l|c|c|c|c|c|c|c|c}
\hline Lake & Latitude & Longititude & Alt (m.a.s.l) & $\mathbf{Z}_{\text {mean }}(\mathbf{m})$ & $\mathbf{Z}_{\text {max }}(\mathbf{m})$ & $\mathbf{L}_{\mathbf{a}}\left(\mathbf{k m}^{2}\right)$ & TL & $\begin{array}{c}\text { Lake } \\
\text { type }\end{array}$ \\
\hline Trichonis & 38.573333 & 21.552222 & $18^{\dagger}$ & $30^{\dagger}$ & $57^{\ddagger}$ & 96.5 & $\mathrm{OL}^{\dagger} \mathrm{MT}^{\S}$ & $\mathrm{WMM}^{\dagger}$ \\
\hline Lysimachia & 38.558597 & 21.376873 & $16^{\dagger}$ & 3 & 9 & 13.1 & $\mathrm{ET}^{\mid}$ & $\mathrm{WMM}^{\mid}$ \\
\hline Amvrakia & 38.652150 & 21.219867 & $16^{\dagger}$ & 23 & 53 & 11.8 & $\mathrm{MT}^{\#}$ & $\mathrm{WMM}^{\#}$ \\
\hline
\end{tabular}

†acharias et al. (2002), `Skoulikidis et al. (1998), ${ }^{\circledR}$ Doulka and Kehayias (2008), 'Leonardos (2004), 'Albanakis et al. (1995), ${ }^{*}$ Danielidis et al. (1996) 


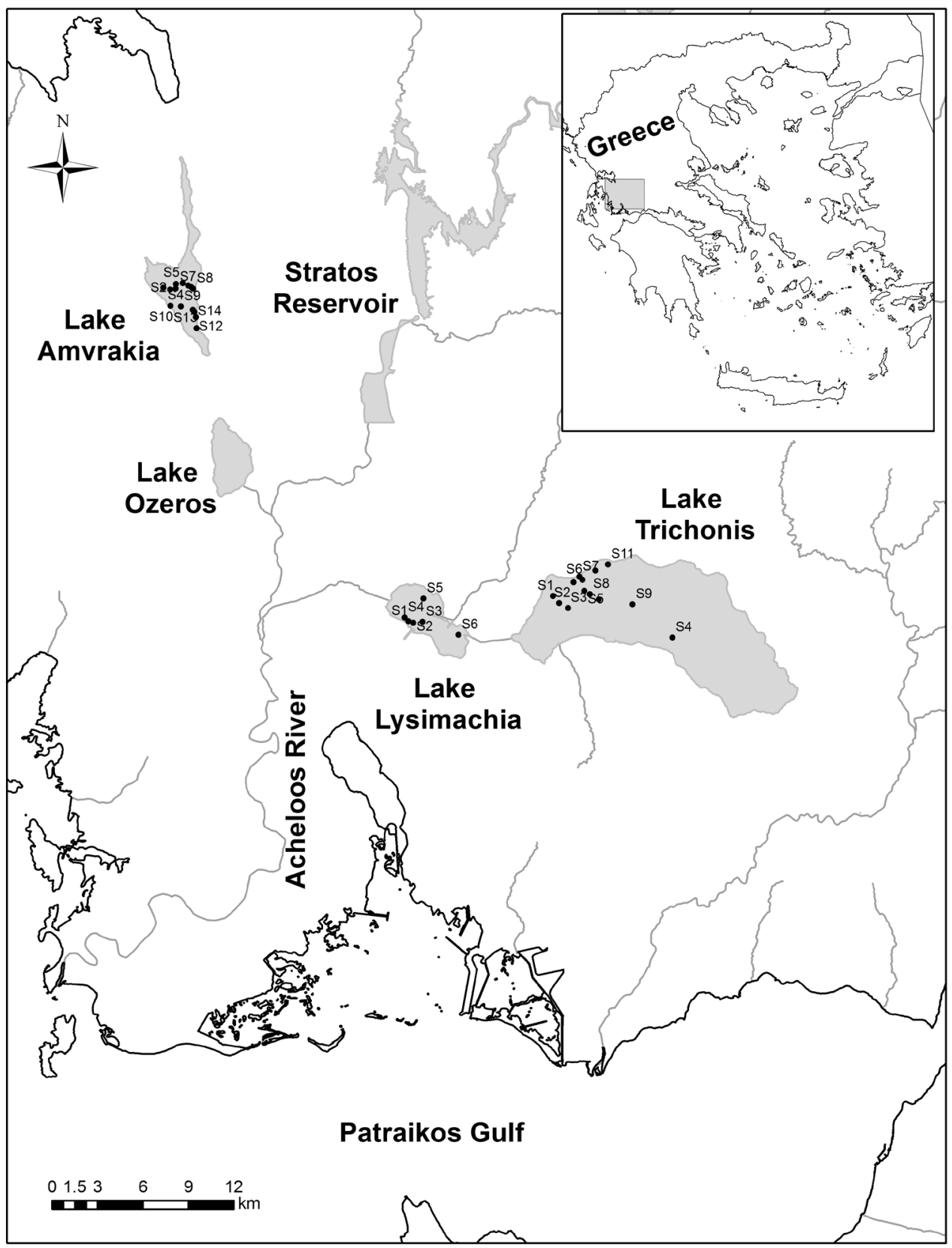

Figure I. Geographical location of the studied lakes and sampling stations.

in $70 \%$ ethanol. After sorting, zoobenthos was identified to the lowest possible taxon and abundance was converted to density (ind. $/ \mathrm{m}^{2}$ ). Additionally, at each station, water samples from $1 \mathrm{~m}$ above the bottom of each lake were collected, using a Niskin-type sampler. Environmental parameters such as water temperature (WT, ${ }^{\circ} \mathrm{C}$ ), $\mathrm{pH}$, conduc- 
tivity (Cond, $\mu \mathrm{S} / \mathrm{cm}$ ) and dissolved oxygen concentration ( $\mathrm{DO}, \mathrm{mg} / \mathrm{l}$ ) were measured in situ just above the bottom sediment of each station using the Aqua Read AP-2000 probe (Kent, GB). Secchi depth (Secchi, cm) was also recorded.

\section{Anatomy}

Genitalia of male and female specimens and other soft body characteristics of D. schlickumi from Lake Amvrakia were studied and compared with those of D. thiesseana collected from Lake Trichonis during the present study and with some additional individuals collected in 2016 (Figure 2). Before dissection, the shells of the specimens studied were removed by soaking in Perenyi solution, following Hershler and Ponder's (1998) morphological terminology. The characterisation of the nervous system was based on Davis et al. (1986) and its concentration was measured as the RPG ratio (Davis et al. 1976).

\section{Morphometry}

Shell morphometry was recorded in both $D$. thiesseana (Trichonis: 33 individuals and Lysimachia: 5 individuals) and D. schlickumi (Amvrakia: 44 individuals) in well preserved shells of adult specimens, using the software ImageFocus v3.0.0.1. Seven linear measurements were taken, specifically: shell height $(\mathrm{H})$, shell width $(\mathrm{W})$, shell aperture height $(\mathrm{Ha})$, shell aperture width (Wa), spire height $(\mathrm{SH})$, body whorl height $(\mathrm{BWH})$ and penultimate whorl height (PWH) (Figure 3). Measurements were then expressed as ratios: shell height/shell width $(\mathrm{H} / \mathrm{W})$; shell aperture height/shell aperture width (Ha/Wa); spire height/body whorl height (SH/BWH), penultimate whorl height/body whorl height (PWH/BWH) and body whorl height/shell width (BWH/W). Prior to further analyses, all the linear measurements and the ratios were logarithmically transformed for normalisation. Subsequently, the t-test for independent samples was performed for detecting significant differences $(p<0.05)$ between the two species using the statistical software SPSS v22.

The studied populations were also tested for morphological diversification using a landmark-based method of acquiring geometrical data of shape and size. Shell variation has been traditionally quantified through linear measurements and ratios to distinguish between individuals and populations, amongst and within snail species. Recently, geometric morphometrics (GMs) have been employed for examining shells, both to provide direct size-free analyses of shell shape (Conde-Padin et al. 2007b, Hayes et al. 2007) and to answer broader evolutionary questions (Pfenninger and Magnin 2001, Conde-Padin et al. 2007a, Haase and Misof 2009, Páll-Gergely et al. 2012, Giokas et al. 2014). GMs have the advantage over traditional morphometrics in being, theoretically, free of effects due to size, position, rotation and scale (Rohlf and Marcus 1993). 


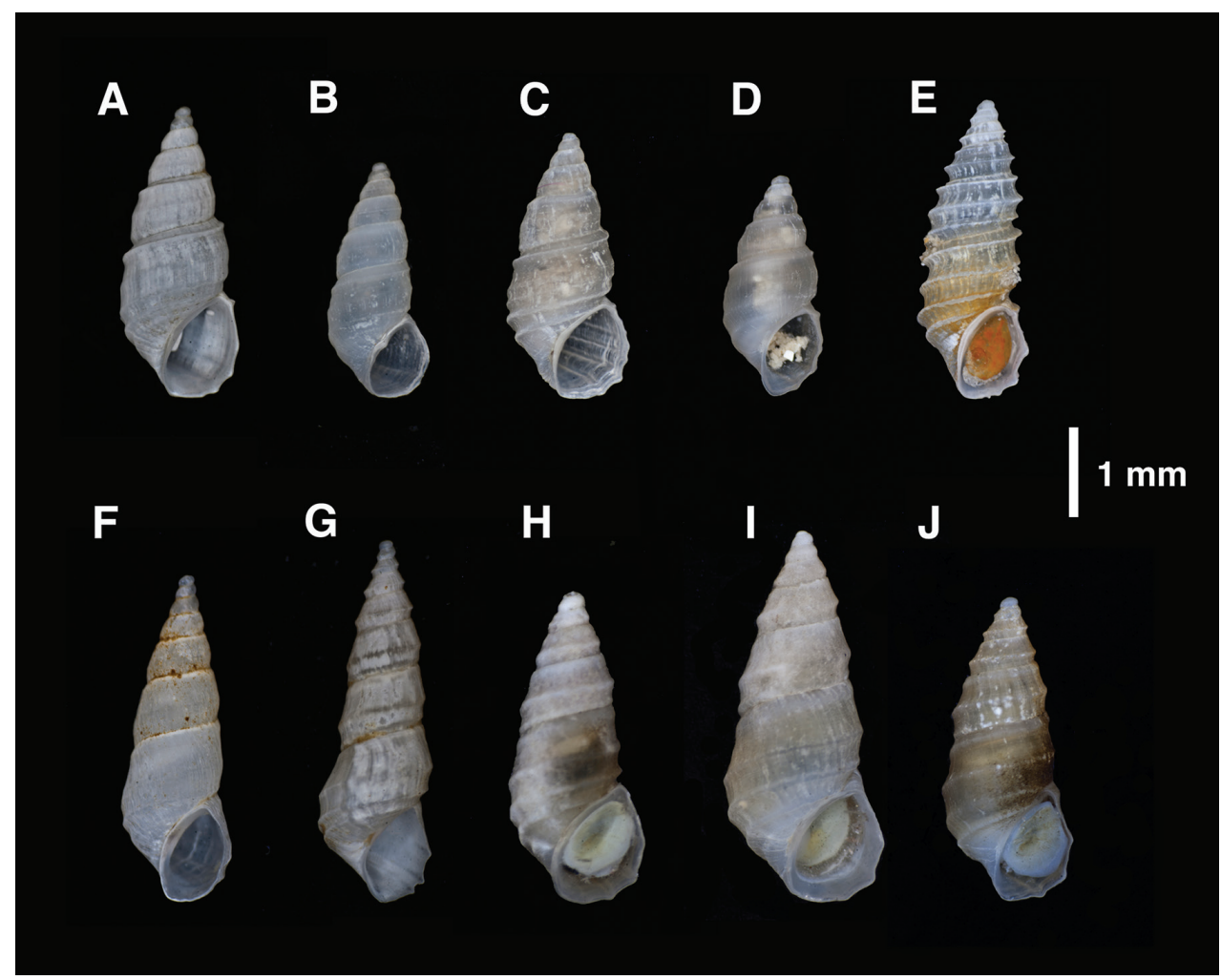

Figure 2. Specimens of: Dianella schlickumi from Lake Amvrakia (A-E) and Dianella thiesseana from Lake Trichonis (F-J), demonstrating their large inter-specific variation of shell morphology.

For that purpose, we used sub-samples of the undamaged and well preserved shells of adult specimens (i.e. 15 D. schlickumi and 9 D. thiesseana specimens), using the aperture features. Specimens were set down on the same plane, with the aperture facing up and we took digital photographs of them. Geometric morphometric variables of the shells were obtained with 18 landmarks (LM) representing the outline of the shell and of the aperture as shown in Figure 4. Landmarks were digitised using tpsDig (Rohlf 2006) and occupied the same positions over the sum of the specimens. Two of these (LM1 and LM18) were of type I (developmentally homologous), 12 landmarks (LM2-LM13) represented suture lines and were considered type II (geometrically homologous). The remaining landmarks were either extreme points on surfaces or were placed halfway between other landmarks, making them type III (Bookstein 1991, Zelditch et al. 2004).

All geometric morphometric analyses were performed with MorphoJ (Klingenberg 2011). The coordinates of shape to be used for further statistical analysis were obtained with Procrustes generalised least squares superimposition. This method excludes the impact of size on the shape of the shell and, theoretically, variations independent of shape are removed using this analysis (Zelditch et al. 2004). Size variables 

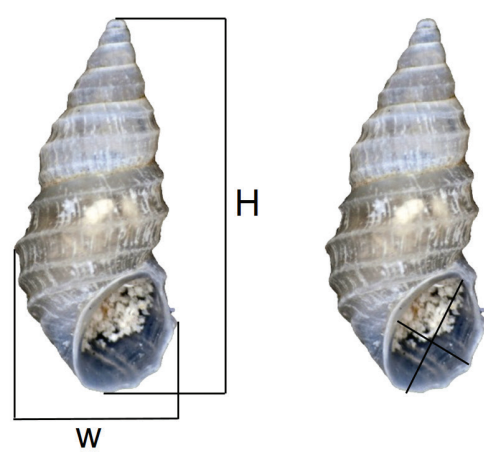

$\mathrm{Ha} / \mathrm{Wa}$

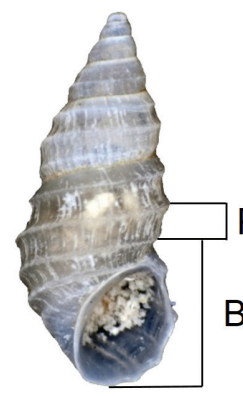

$\mathrm{PWH}$

BWH

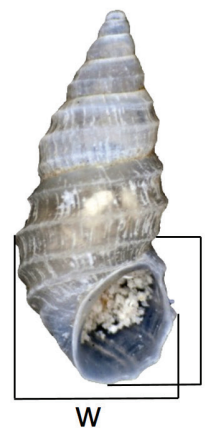

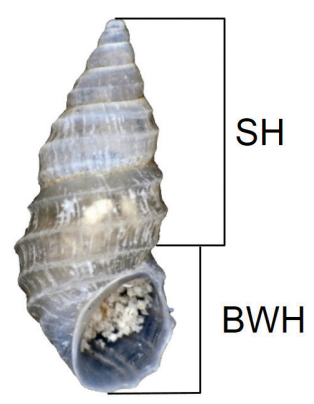

$\mathrm{H}$ : shell height

W: shell width

Ha: shell aperture height

Wa: shell aperture width

$\mathrm{SH}$ : spire height

BWH: body whorl height

PWH: penultimate whorl height

Figure 3. External morphological measurements taken in specimens of Dianella schlickumi and Dianella thiesseana.

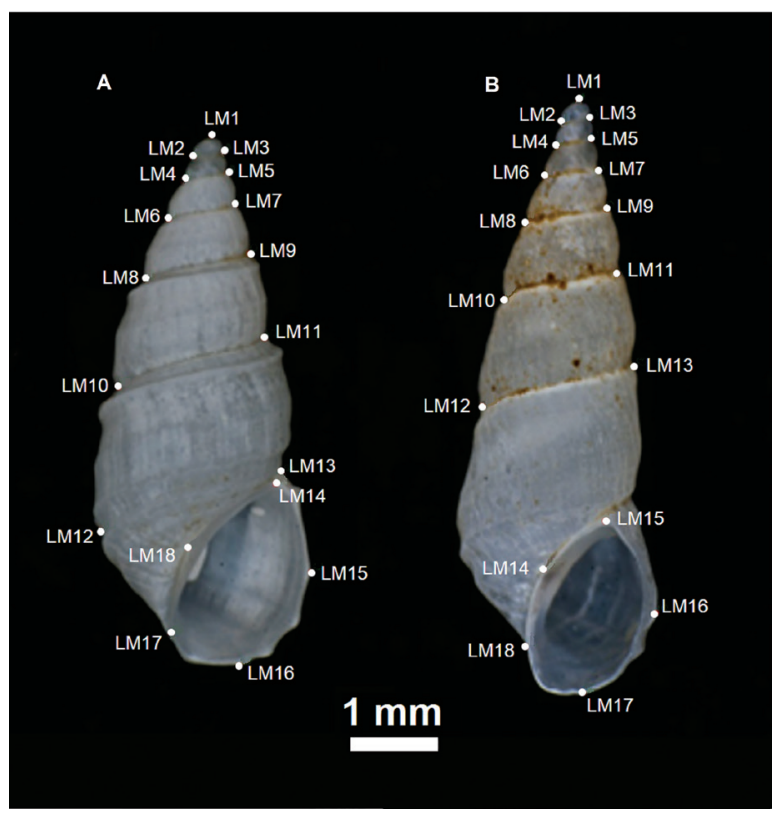

Figure 4. Dianella schlickumi and Dianella thiesseana specimens positioned with the axis of the shell on the $y$-axis and the aperture in the same plane as the objective, showing the location of the 18 landmarks (LM1-LM18) used. A D. schlickumi B D. thiesseana. 
(centroid size) for each specimen were also generated. We examined, using pooled within-group regression analysis, the effect of centroid size on shape, regressing to the resulting Procrustes coordinates on centroid size. That regression score was not significant (Permutation test, 10,000 rounds against the null hypothesis of independence, \% predicted $=6.170, p=0.2183$ ). Therefore, we eventually used the Procrustes coordinates, which were analysed with Principal Component Analysis (PCA) and Canonical Variate Analysis (CVA) in order to explore the morphological variation between the two Dianella species. The reliability of the discrimination was assessed by leave-oneout cross-validation.

\section{Analyses of abundance and environmental data}

Detrended Correspondence Analysis (DCA) (indirect gradient analysis) (programme CANOCO version 4.5.1; Ter Braak and Šmilauer 1998) was performed to abundance data in order to verify if they corresponded linearly to the environmental gradient or if abundances peaked around an environmental optimum (unimodal response) (Ter Braak and Šmilauer 1998). In this study, the species abundance data corresponded roughly linearly to the gradient, because the length of the gradient of the first axis was three times less than the range of the within-sample standard deviation (Ter Braak and Šmilauer 1998). Thus, Redundancy Analysis (RDA) was further applied to link the environmental parameters to species abundance data. The Monte Carlo permutation test was performed to select the statistically significant $(p<0.05)$ environmental parameters that explain most of the variance of species abundance, while the variation inflation factor $(>20)$ was used to assess the interrelation of the parameters.

\section{Results}

\section{Species distribution}

Dianella schlickumi was found at the south-east part of Lake Amvrakia, in 5 (S7, S11, S12, S13, S14; Figure 1) out of the 14 stations (36\%) surveyed, at depths ranging from $5 \mathrm{~m}$ to $13 \mathrm{~m}$. No individuals were recorded at its western part (S9 and S10, Figure 1), not even empty shells. The highest abundance was recorded at station S15 (607 ind./ $\mathrm{m}^{2}$ ) at depth $5 \mathrm{~m}$ (Table 2). D. thiesseana was found in 2 (S6 and S13) out of the 13 stations (15\%) in Lake Trichonis, located on the northeast side of the lake, at depths of $13 \mathrm{~m}$ to $18 \mathrm{~m}$ (Figure 1, Table 2). During the current study, only empty shells from $D$. thiesseana were collected in Lake Lysimachia. However, the presence of a live $D$. thiesseana was confirmed in the east side of Lake Lysimachia by surveys executed during the National Water Monitoring Programme in spring 2015 (Mavromati, personal communication). Both species were present during the spring surveys while none was found during autumn. 
Table 2. Dianella schlickumi and Dianella thiesseana abundances (number of individuals sampled by Ekman-Birge grab, $225 \mathrm{~cm}^{2}$ sampling area) per sampling station and environmental parameters measured in lakes Trichonis, Lysimachia and Amvrakia.

\begin{tabular}{|c|c|c|c|c|c|c|c|c|c|}
\hline \multirow[b]{2}{*}{ Lake } & \multirow[b]{2}{*}{ Station } & \multicolumn{2}{|c|}{ Abundance (ind. $/ \mathrm{m}^{2}$ ) } & \multicolumn{6}{|c|}{ Environmental parameters } \\
\hline & & $\begin{array}{c}\text { Dianella } \\
\text { schlickumi }\end{array}$ & $\begin{array}{l}\text { Dianella } \\
\text { thiesseana }\end{array}$ & $\begin{array}{c}\text { Depth } \\
\text { (m) }\end{array}$ & $\begin{array}{c}\text { Secchi } \\
(\mathbf{m})\end{array}$ & $\begin{array}{c}\text { DO } \\
(\mathrm{mg} / \mathrm{l})\end{array}$ & $\mathrm{pH}$ & $\begin{array}{l}\text { Cond } \\
(\mu \mathrm{S} / \mathrm{cm})\end{array}$ & $\begin{array}{l}\text { WT } \\
\left({ }^{\circ} \mathrm{C}\right) \\
\end{array}$ \\
\hline \multirow{2}{*}{ Trichonis } & 56 & & 59 & 18.0 & 6.4 & 9.05 & 10.04 & 319 & 18.8 \\
\hline & S13 & & 44 & 13.0 & 5.6 & 8.92 & 10.73 & 320 & 15.0 \\
\hline Lysimachia & LYS & & 15 & 3.8 & 1.7 & 9.77 & 8.13 & 363 & 11.9 \\
\hline \multirow{5}{*}{ Amvrakia } & S7 & 15 & & 13.0 & 5.2 & 8.87 & 9.74 & 982 & 21.2 \\
\hline & S11 & 15 & & 8.0 & 4.7 & 8.38 & 10.10 & 921 & 20.5 \\
\hline & $S 12$ & 44 & & 11.5 & 4.8 & 8.48 & 10.48 & 922 & 20.5 \\
\hline & $S 13$ & 44 & & 9.0 & 5.1 & 8.66 & 10.42 & 916 & 21.6 \\
\hline & S14 & 607 & & 5.0 & 3.2 & 8.47 & 10.62 & 898 & 20.9 \\
\hline
\end{tabular}

\section{Soft body anatomy of $D$. schlickumi}

Ctenidium-Osphradium: Ctenidial filaments broader than high; osphradium elongate, approximately opposite to the middle of ctenidium.

Nervous system (Figure 5A): Cerebral ganglia similarly sized, white; supraoesophageal and suboesophageal ganglia white; supraoesophageal connective much longer than the suboesophageal. Nervous system extremely elongate, RPG ratio 0.75 .

Gastric caecum: Large and elongate gastric caecum on the posterior stomach chamber. Rectum: The U-shaped intestine loop in the pallial cavity roof was wide and the faecal pellets were packed sideways (Figure 5B).

Female reproductive system (Figure 6A): Pallial oviduct glands with straight border; bursa copulatrix medium-sized, ovoid-globular, positioned posteriorly to the albumen gland; bursal duct long; renal oviduct unpigmented, coiled tightly with more than two bends; typical seminal receptacles absent; a beak-shaped dilatation of oviduct in the position of seminal receptacle rs2, anteriorly to the bursa.

Penis (Figure 6B): Penis large, gradually tapered, proximal part folded, penial base of medium width, its attachment area central and well behind the head, penial duct almost straight located at the outer edge of the penis.

Egg capsule (Figure 6C-D): Several lenticular and transparent egg capsules (each one containing a single egg) in various growth stages were found on the external shell surface of two specimens.

\section{Morphometry}

Seven out of the 12 morphometric measurements taken, differed statistically ( $p$ $<0.001$ ) between the two species. Generally, individuals of $D$. thiesseana exhibited higher mean values compared to $D$. schlickumi, except for SH/BWH ratio, which was higher in D. schlickumi (Table 3). 


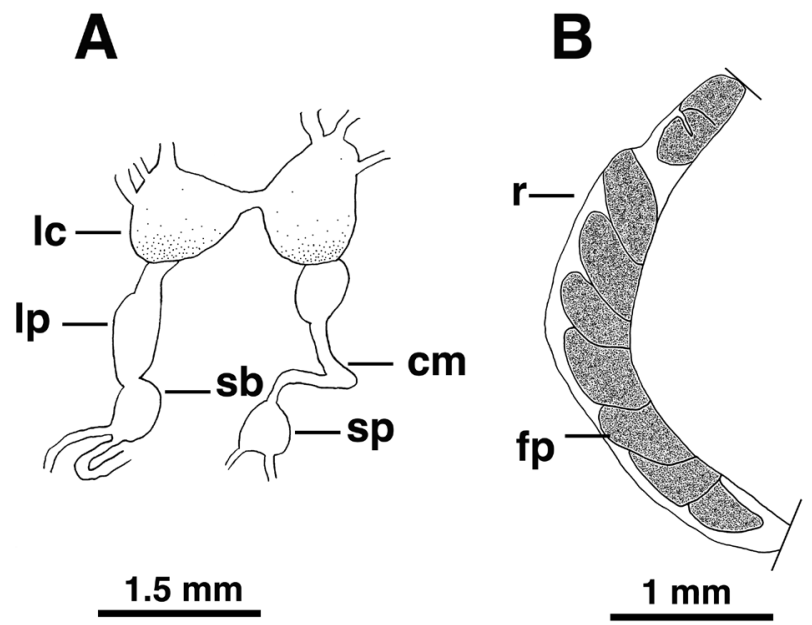

Figure 5. Non-genital anatomy of Dianella schlickumi. A Nervous system B Rectum full of faecal pellets. Abbreviations: cm -commissure; fp -faecal pellets; lc -left cerebral ganglion; lp -left pleural ganglion; sb - suboesophageal ganglion; sp -supraoesophageal ganglion; $r$-rectum.

Table 3. Average ( \pm standard error) and range (minimum and maximum values) of the morphometric measurements (in $\mathrm{mm}$ ) taken in Dianella thiesseana and Dianella schlickumi specimens. The results of $\mathrm{t}$-test are also provided (* indicates the significant differences). $\mathrm{n}=$ number of individuals used: $\mathrm{H}$ : shell height; W: shell width; Ha: shell aperture height; Wa: shell aperture width; SH: spire height; BWH: body whorl height; PWH: penultimate whorl height.

\begin{tabular}{|c|c|c|c|c|}
\hline \multirow{2}{*}{ Variables } & \multirow{2}{*}{$\begin{array}{c}\begin{array}{c}\text { Dianella thiesseana } \\
(\mathrm{n}=38)\end{array} \\
\end{array}$} & \multirow{2}{*}{$\begin{array}{c}\text { Dianella schlickumi } \\
(\mathrm{n}=44)\end{array}$} & \multicolumn{2}{|c|}{ t-test } \\
\hline & & & $F$ & $p$ \\
\hline $\mathrm{H}$ & $6.79 \pm 0.25(4.16-9.78)$ & $6.17 \pm 0.21(4.34-10.89)$ & 3.95 & 0.063 \\
\hline $\mathrm{W}^{*}$ & $3.01 \pm 0.07(2.20-3.86)$ & $2.65 \pm 0.06(1.93-3.75)$ & 0.40 & $<0.001$ \\
\hline $\mathrm{Ha}^{*}$ & $2.45 \pm 0.06(1.58-3.16)$ & $2.07 \pm 0.04(1.61-2.92)$ & 1.45 & $<0.001$ \\
\hline $\mathrm{Wa}^{*}$ & $1.67 \pm 0.04(1.18-2.22)$ & $1.45 \pm 0.03(1.05-1.91)$ & 0.04 & $<0.001$ \\
\hline $\mathrm{SH}$ & $4.10 \pm 0.19(2.05-6.38)$ & $3.97 \pm 0.17(2.50-7.70)$ & 8.87 & 0.797 \\
\hline $\mathrm{BWH}^{*}$ & $2.69 \pm 0.07(2.00-3.77)$ & $2.20 \pm 0.05(1.64-3.25)$ & 0.86 & $<0.001$ \\
\hline $\mathrm{PWH}^{*}$ & $0.67 \pm 0.02(0.34-0.92)$ & $0.54 \pm 0.01(0.34-0.78)$ & 5.23 & $<0.001$ \\
\hline $\mathrm{H} / \mathrm{W}$ & $2.24 \pm 0.06(1.69-3.14)$ & $2.31 \pm 0.04(1.99-3.29)$ & 3.09 & 0.250 \\
\hline $\mathrm{Ha} / \mathrm{Wa}$ & $1.47 \pm 0.02(1.19-1.82)$ & $1.44 \pm 0.02(1.16-1.93)$ & 0.85 & 0.255 \\
\hline SH/BWH* & $1.52 \pm 0.06(0.87-2.37)$ & $1.80 \pm 0.04(1.36-2.89)$ & 12.14 & $<0.001$ \\
\hline $\mathrm{PWH} / \mathrm{BWH}$ & $0.25 \pm 0.01(0.16-0.38)$ & $0.25 \pm 0.00(0.17-0.32)$ & 0.62 & 0.731 \\
\hline $\mathrm{BWH} / \mathrm{W}^{*}$ & $0.89 \pm 0.01(0.77-1.09)$ & $0.83 \pm 0.01(0.73-0.98)$ & 0.15 & $<0.001$ \\
\hline
\end{tabular}

Geometric morphometric analysis revealed a clear size and shape distinction between the two Dianella species. Shells of $D$. thiesseana were significantly larger (Centroid Size) than those of D. schlickumi $\left(F_{1,22}=38.01, p<0.0001\right.$, Figure 8). The landmark-based analyses of individual shells also confirmed a shape distinction between the two species. 
A

\section{$\mathbf{B}$}
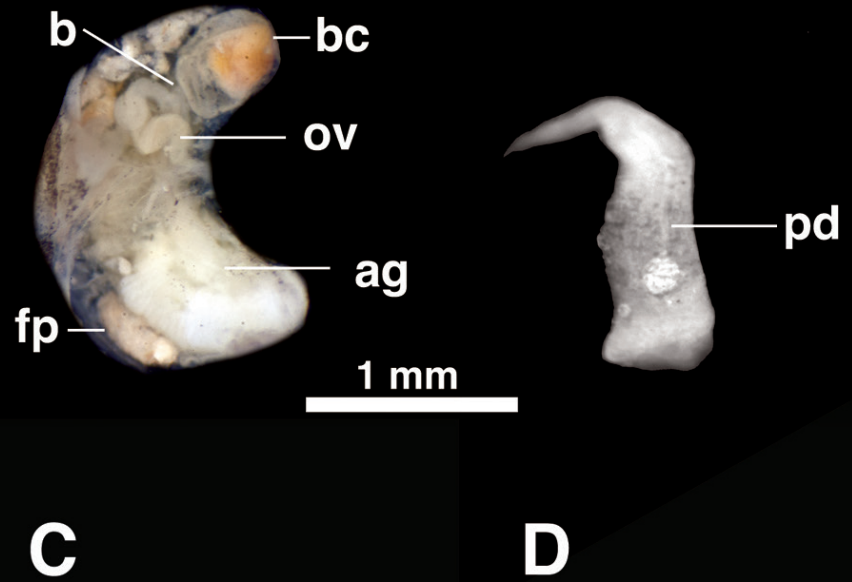

D

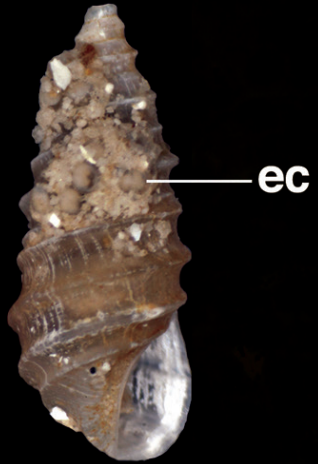

$2.5 \mathrm{~mm}$

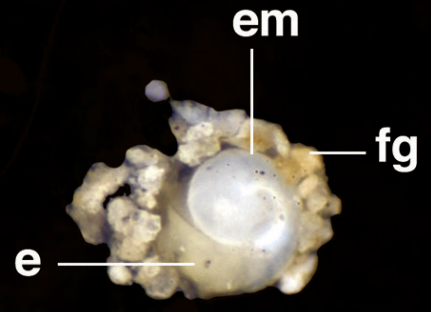

Figure 6. Genital anatomy and egg capsules of Dianella schlickumi. A Female genitalia B Penis C Shell bearing egg capsules covered by fine-grained material D Egg capsule with embryo. Abbreviations: agalbumen gland; b-beak-shape dilatation of the oviduct; bc-bursa copulatrix; fp-faecal pellets; fg-finegrained material; e-eye; ec-egg capsules; em-embryo; ov: renal oviduct; pd-penial duct.

ANOVA of Procrustes coordinates also showed a clear shape difference between the two species $\left(F_{32,704}=20.78, p<0.0001\right)$. PCA of Procrustes coordinates, which aimed at finding linear combinations maximising the total variance, revealed three principal components (PC1-PC3) explaining $88.1 \%$ of the total variance. The distinction between the two species was quite evident along the PC1 axis (Figure 9). In the CVA, which maximised differentiation amongst species (or predefined groups), the first and only extracted canonical variate 


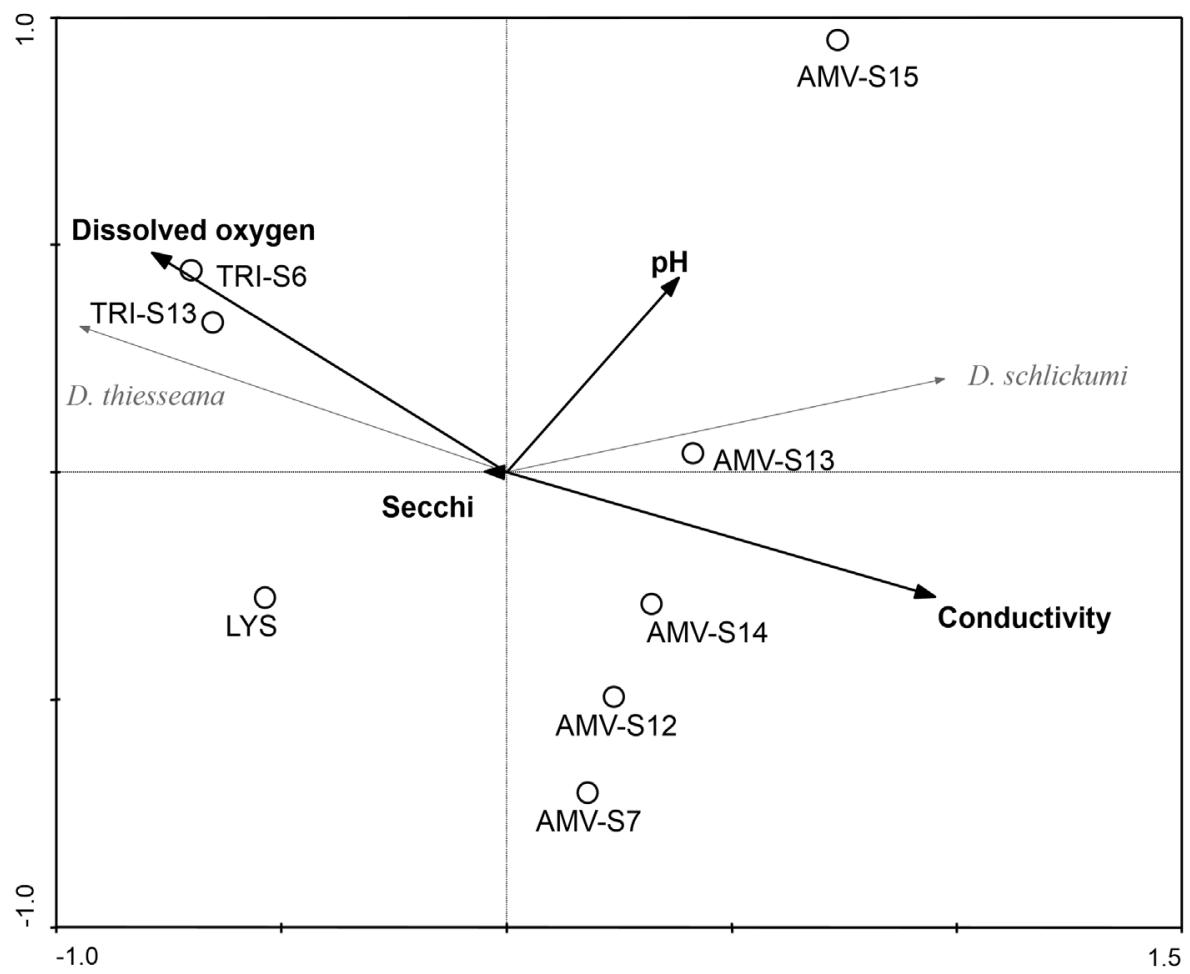

Figure 7. RDA ordination diagram of Dianella thiesseana and Dianella schlickumi abundances at sampling sites (circles) in relation to environmental parameters in lakes Trichonis (TRI), Lysimachia (LYS) and Amvrakia (AMV) in spring 2014 and 2015.

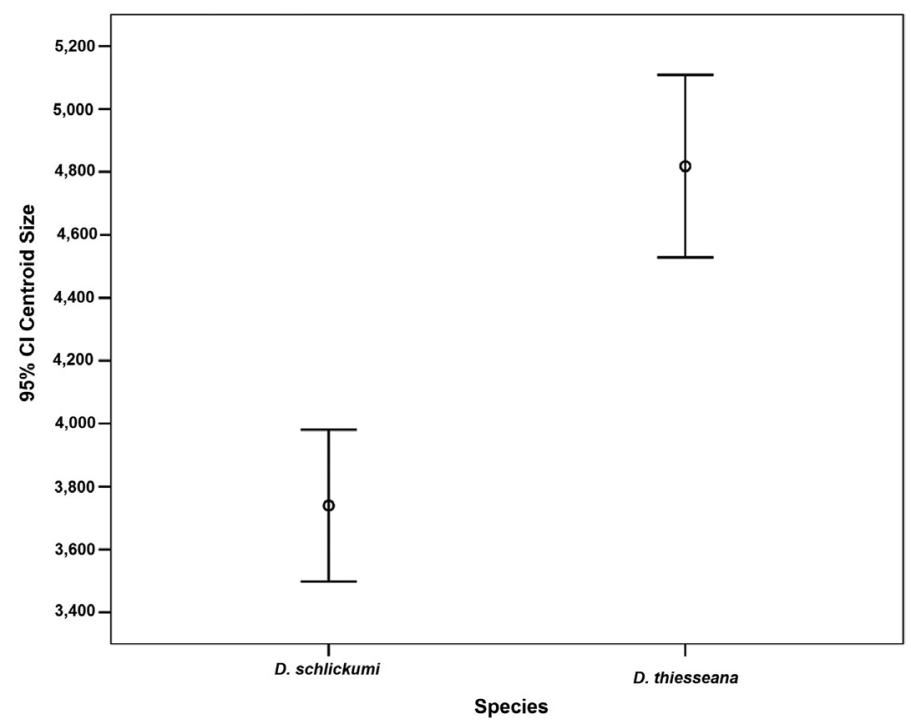

Figure 8. Means $\pm 95 \%$ Confidence Intervals of centroid size for the two Dianella species and their ordinations based on landmark data. 


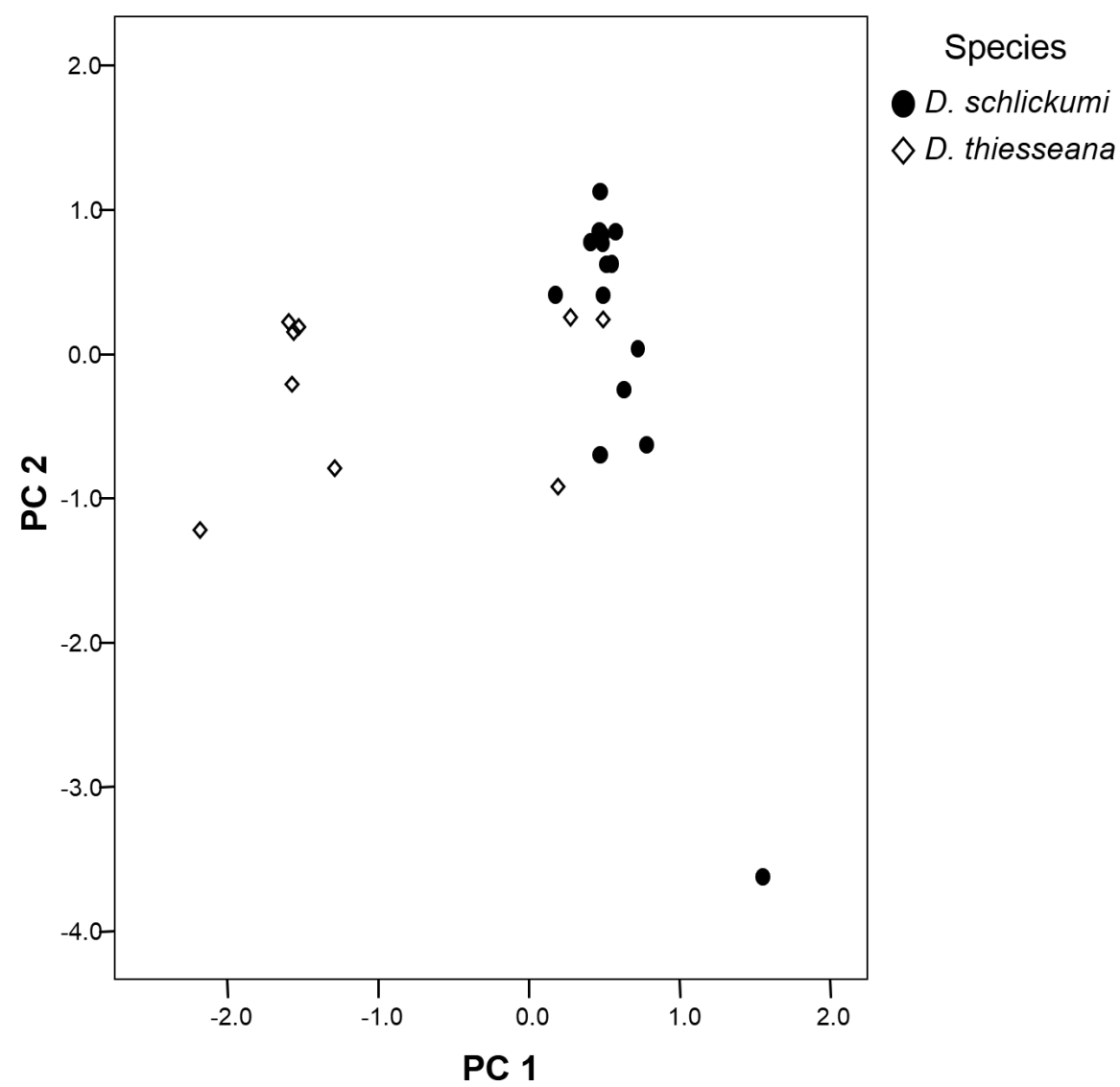

Figure 9. Principal component analysis of Procrustes coordinates for Dianella schlickumi (black circles) and for Dianella thiesseana (open diamonds).

(CV1) explained $100 \%$ of total variation and showed a much clearer separation than PCA between the two morphotypes along the CV axis (Figure 10). Clear shape discrimination was also found between $D$. thiesseana and $D$. schlickumi shells after a permutation Discriminant Function Analysis (T-squared $=236.3713, \mathrm{p}$ (parametric) $=0.8335, p$ (permutation) $<0.0001$ ). However, after a permutation test with 1,000 replicates, only $54.2 \%$ of "unknown" individuals (leave-one-out cross-validation) were correctly classified. Shape changes along the CV1 are shown in Figure 11 and portray the tendency for D. thiesseana to be slimmer compared to D. schlickumi and also to have a larger, i.e. elongated, aperture.

\section{Environmental parameters}

The Monte Carlo test in RDA analysis revealed two out of the six environmental parameters examined as significantly different between the two species $(p<0.05)$ : conductivity and Secchi depth. Depth and water temperature were excluded from the analysis 


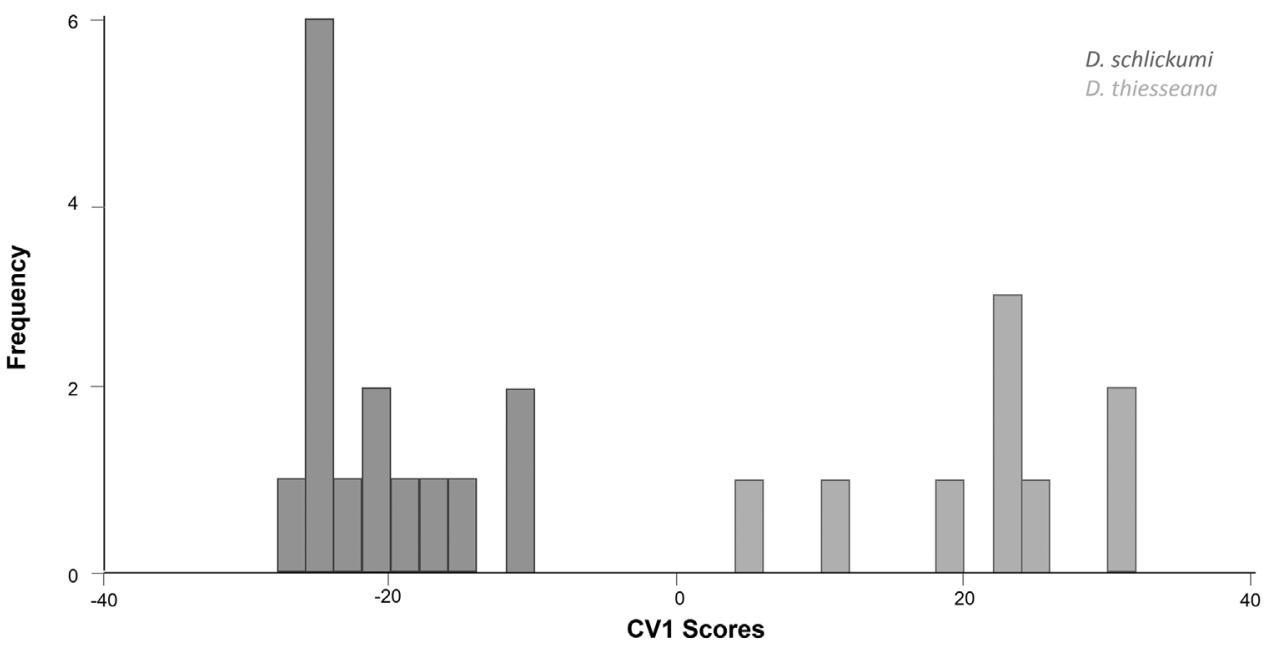

Figure 10. Canonical Variate Analysis: Dark-grey bins stand for Dianella schlickumi specimens and lightgrey bins for Dianella thiesseana specimens.

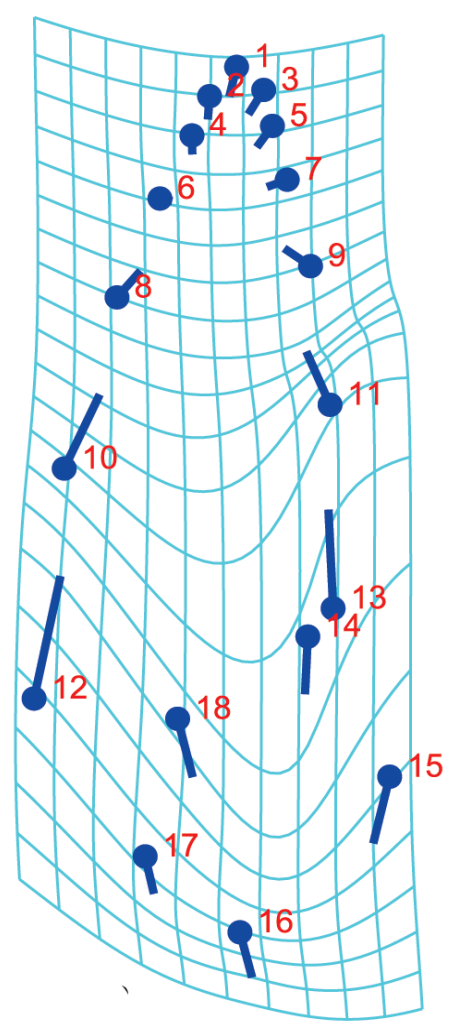

Figure I I. Shape changes along the CV1: the shifts of landmark positions are indicated by straight lines. Each line starts with a dot at the location of the landmark in the starting shape (i.e. Dianella schlickumi). The length and direction of the line indicate the movement of the respective landmark towards the final shape (i.e. Dianella thiesseana). 
due to their high inflation factor $(>20)$. The first and all canonical axes were statistically significant $(p=0.044$ and $p=0.002$ respectively). The first two ordination axes of RDA explained $99.5 \%$ of the total species variance (Monte Carlo test, $p<0.05$ ). Axis I (eigenvalue $0.929, p<0.05$ ) was related to conductivity and DO (intra-set correlation values 0.952 and -0.788 respectively) and Axis II (eigenvalue 0.066 ) to $\mathrm{pH}$ (intra-set correlation value 0.428). D. schlickumi specimens from Lake Amvrakia were ordered at the positive side of Axis I, having the highest conductivity values while $D$. thiesseana specimens from the other lakes were ordered at the negative side of Axis I and correlated with lower values of conductivity and higher values of DO (Figure 7, Table 2).

\section{Discussion}

Dianella schlickumi was recorded in the sublittoral zone of Lake Amvrakia in 1962 (Schütt 1962), but no exact details about this location were provided. The latest record confirming the presence of the species in the lake was before 1983 (Radoman 1983). After that, D. schlickumi was assumed to be extinct, as reported by Reischütz and Reischütz (2002), Szarowska et al. (2005) and Albrecht et al. (2006), based on sampling efforts in 1983, 2002 and 2003 respectively. Albrecht et al. (2011a) mentioned that the originally recorded area of D. schlickumi is the northern extent of Lake Amvrakia. At this part of the lake water, level fluctuations were high during the last years, due to insufficient connectivity with the main body of the lake. In fact, during extremely dry summers, this area is completely dry or water remains only in small pools. In such cases, the predation pressure (mainly from fish) is intense, resulting in local extinction of molluscs (Nilsson et al. 2008, Downing et al. 2010). Such rough conditions have probably negatively affected the population size and the distribution of D. schlickumi in this lake. Nevertheless, in our study, we were able to collect specimens of various ages at several sampling sites, indicating that this snail is still extant and thriving in its type locality.

Under the IUCN Red List guidelines (IUCN 2017), D. schlickumi is considered as "Critically Endangered (Possibly Extinct)" [following the criteria B1ab (i, iii)] (Albrecht et al. 2011a). However, since a viable population of this species was demonstrated in the present study, the tag "Possibly Extinct" should be removed from its assessment. The rediscovery of the species does not however improve its conservation status, as its extent of occurrence is estimated to be less than $100 \mathrm{~km}^{2}$, restricted to the sublittoral zone of Lake Amvrakia $\left(<10 \mathrm{~km}^{2}\right)$. Moreover, D. schlickumi is known to exist only in a single location, where habitat degradation was also noticed due to agricultural practices and pesticide contamination (Thomatou et al. $2013 \mathrm{a}, \mathrm{b}$ ). Consequently, the classification of Critically Endangered should be maintained, as the IUCN criteria continue to be met. As for D. thiesseana, it should also continue to be considered as Critically Endangered [B1ab (ii, iii) and 2ab (ii, iii)] since it has an extent of occurrence of 94 $\mathrm{km}^{2}$ and an area of occupancy of $2 \mathrm{~km}^{2}$. Its habitat is also degraded because of intensive agricultural practices, urban sewage, stock grazing land and small industries (Bertahas et al. 2006). 
Both species thrive on soft substrate (Albrecht et al. 2011a, b). D. schlickumi seemed to prefer slightly shallower habitats, from $3 \mathrm{~m}$ to $15 \mathrm{~m}$, while $D$. thiesseana had a range of distribution from $2.5 \mathrm{~m}$ to $27 \mathrm{~m}$. The species absence from autumn surveys may be due to depth migrations often observed in gastropods (Brown 2001). Even though this study has confirmed the rediscovery of $D$. schlickumi, it does not clarify in detail the accurate distribution of the species, which might be the subject of future research.

The anatomical characters of D. schlickumi known from literature (Schütt 1962) (i.e. the radula) and those described in the present paper (i.e. the ctenidium and osphradium, the central nervous system, the gastric caecum, the rectum and the male and female reproductive organs) are similar to those reported by Radoman (1983) in the diagnosis of the family Pyrgulidae Brusina 1881 (nominal subfamily Pyrgulinae) and of the genus Dianella Gude, 1913 [(type species Dianella thiesseana (Kobelt, 1878)]. Similarities have also been found between $D$. schlickumi and D. thiesseana in the nervous system, the gastric caecum and the female reproductive organs as they are described for the latter species by Szarowska et al. (2005, pp. 22-31 and related figures). However, a notable difference exists in the shape of the penis between the two species: the penis of $D$. thiesseana is wide, with a triangular shape due to its expanded base and has a clear outgrowth on its left side (Szarowska et al. 2005, p. 29, figs 32-37). The penis of D. schlickumi does not have an expanded base and is gradually tapering without any distinct outgrowth.

D. schlickumi and D. thiesseana are discriminated due to their shell dimensions; the first one is smaller than the second (Radoman 1983). In our study, traditional and geometric morphometric analyses support the assumption that $D$. thiesseana and $D$. schlickumi are quite distinguishable in terms of external morphology. However, neither in the original description of the two taxa (Kobelt 1878 and Schütt 1962 respectively) nor in the subsequent studies (Radoman 1983, Szarowska et al. 2005), shell shape appears to be significantly different between the two taxa. Moreover, Szarowska et al. (2005) reported that the shell characters and dimensions of D. schlickumi, described in the literature and those of $D$. thiesseana from Lake Lysimachia, lie within the range observed for $D$. thiesseana from Lake Trichonis. Even though, the intra-subspecific morphometric variation is quite high, the two species are actually distinct in size and shape (Figures 8-10). Therefore, in the "Dianella" case, geometric morphometric analysis has been proved to be a useful tool for exploring patterns of species diversity and seems promising for examining morphological adaptations of these species. Specifically, it is clear that the Centroid Size, derived from Geometric Morphometric Analysis, can be used safely to distinguish those two species.

In some cases, the environmental parameters set limits (Pyron and Brown 2015) and may influence (Økland 1983, Pip 1986, Falniowski 1987) the distribution of freshwater snails. The analysis performed revealed conductivity, $\mathrm{DO}$ and $\mathrm{pH}$ as the most significant parameters explaining the current species variance. D. thiesseana, according to RDA, seems to prefer more oxygenated waters with lower conductivity values and $\mathrm{pH}$ than D. schlickumi. Conductivity, dissolved oxygen (e.g. Çabuk et al. 2004, Kazibwe et al. 2006, Cloherty and Rachlin 2011) and pH (Økland 1983, Pip 1986, Çabuk et al. 2004) are also referenced as key environmental proxies explaining 
gastropods distribution in water bodies. Biological interactions and/or historical factors, which need further surveys and analyses, may also be responsible.

Both Dianella species require urgent conservation measures to be enforced and suitable management plans to be implemented in the whole studied area, focusing on the protection of these species and the improvement of their habitats. The studied lakes form an ecologically important complex as Special Conservation areas (Council Directive 92/43/EEC), listed in the NATURA 2000 network. However, the integrity of local mollusc populations in these ecosystems is threatened due to the presence of invasives; Ferrissia fragilis (Tryon, 1863) and Physa acuta Draparnaud, 1805 in lakes Trichonis and Lysimachia (Albrecht et al. 2014) and of Potamopyrgus antipodarum (J.E. Gray, 1843) in Lake Trichonis (Radea et al. 2008). The invasive impacts upon native molluscs may be direct, through competition for food and space (Carlsson et al. 2004 ) or indirect, through changes in ecosystem function and/or parasitism (Brown et al. 2008). The antagonistic behaviour of $P$. antipodarum and $P$. acuta is already wellknown (e.g. Schreiber et al. 2003, Zukowski and Walker 2009), although no such outcomes have been documented for F. fragilis until now (Albrecht et al. 2014). Available knowledge on the effects of invasive species on native mollusc species and especially on D. thiesseana, is insufficient to estimate the possible threats.

One of the main pressures identified in lakes Amvrakia, Trichonis and Lysimachia is eutrophication from agriculture run-off and wastewaters (Bertahas et al. 2006, Thomatou et al. 2013 a, b). Dianella inhabits the sublittoral zone of these lakes, which is mainly affected by eutrophication (Pilotto et al. 2012). The development of water quality indices based on zoobenthic communities and related to eutrophication will help to assess the ecological status of these water bodies and prevent their further deterioration. The impacts could be minimised by preserving natural vegetation or establishing buffer zones. Only low-impact activities should be allowed near the lakes and harmful practices should be prohibited or regulated to a more distant zone. Furthermore, it is crucial to restore the type locality of $D$. schlickumi by maintaining the connectivity of the northern extension of Lake Amvrakia with the main lake water body, thus preventing the species' historical distribution area to become dry. Additional measures to reduce water abstraction could help the maintenance of the ecological water level in the lakes, securing slight seasonal fluctuations and preventing aquatic biodiversity in general (Zohary and Ostrovsky 2011). Further temporal and spatial surveys which will identify the ecological features, the ecosystem functions and the habitat preferences of the studied species could significantly support conservation efforts. Environmental education and citizen awareness could additionally support conservation efforts for both endemic gastropods.

\section{Conclusion}

Our results confirm the rediscovery of the narrow endemic species Dianella schlickumi in Lake Amvrakia since past sampling efforts did not detect it for more than 
30 years. Moreover, they provide basic knowledge on its anatomical, morphological and distributional patterns and its discrimination from Dianella thiesseana. The two species are discriminated by their shell size and shape. Moreover, the presence of Dianella thiesseana is confirmed in lakes Trichonis and Lysimachia. We conclude that further conservation measures have to be implemented for effective protection of both species.

\section{Acknowledgements}

We would like to thank Mrs Efi Mavromati from the Greek Biotope/Wetland Centre for providing us with data from the National Greek Monitoring Programme for the presence of Dianella thiesseana in Lake Lysimachia.

\section{References}

Abell R, Allan JD, Lehner B (2007) Unlocking the potential of protected areas for freshwaters. Biological Conservation 134(1): 48-63. https://doi.org/10.1016/j.biocon.2006.08.017

Albanakis C, Vouvalidis K, Palikaridis Ch, Psilovikos AA (1995) Phenomena of anoxic conditions in karstic Lake Amvrakia. Proceedings of $4^{\text {th }}$ Pan-Hellenic Geographical Congress of the Hellenic Geographical Society, Athens (Greece), October 1995, 54-63. http://geolib. geo.auth.gr/index.php/pgc/article/view/9098/8850

Albrecht C, Lohfink D, Schultheiss R (2006) Dramatic decline and loss of mollusk diversity in long-lived lakes in Greece. Tentacle 14: 11-13.

Albrecht C, Wilke T (2008) Ancient Lake Ohrid: Biodiversity and evolution. Hydrobiologia 615(1): 103-140. https://doi.org/10.1007/s10750-008-9558-y

Albrecht C, Hauffe T, Schreiber K, Trajanovski S, Wilke T (2009) Mollusc biodiversity and endemism in the putative ancient Lake Trichonis (Greece). Malacologia 51(2): 357-375. https://doi.org/10.4002/040.051.0209

Albrecht C, Hauffe T, Schreiber K (2011a) Dianella schlickumi. The IUCN Red List of Threatened Species 2011. e.T156088A4891185: https://doi.org/10.2305/IUCN.UK.2011-1.RLTS. T156088A4891185.en

Albrecht C, Hauffe T, Schreiber K (2011b) Dianella thiesseana. The IUCN Red List of Threatened Species 2011. e.T155578A4802619: https://doi.org/10.2305/IUCN.UK.2011-1. RLTS.T155578A4802619.en

Albrecht C, Föller K, Clewing C, Hauffe T, Wilke T (2014) Invaders versus endemics: Alien gastropod species in ancient Lake Ohrid. Hydrobiologia 739(1): 163-174. https://doi. org/10.1007/s10750-013-1724-1

Anistratenko VV (2008) Evolutionary trends and relationships in hydrobiids (Mollusca, Caenogastropoda) of the Azov-Black Sea Basin in the light of their comparative morphology and paleozoogeography. Zoosystematics and Evolution 84(2): 129-142. https://doi. org/10.1002/zoos.200800001 
Bank R (2017) Fauna Europaea: Pyrgulinae. Fauna Europaea version 2.6. Available online at http://www.fauna-eu.org [Accessed on 20 June 2017]

Bertahas I, Dimitriou E, Karaouzas I, Laschou S, Zacharias I (2006) Climate change and agricultural pollution effects on the trophic status of a Mediterranean lake. CLEAN-Soil, Air. Water (Basel) 34: 349-359. https://doi.org/10.1002/aheh.200500637

Bookstein FL (1991) Morphometric Tools for Landmark Data: Geometry and Biology. Cambridge University Press, 1-512. https://doi.org/10.1002/bimj.4710350416

Brown K (2001) Mollusca: Gastropoda. In: Thorp JH, Covich AP (Eds) Ecology and classification of North American freshwater invertebrates. Academic press, California, 297-329.

Brown KM, Lang B, Perez KE (2008) The conservation ecology of North American pleurocerid and hydrobiid gastropods. Journal of the North American Benthological Society 27(2): 484-495. https://doi.org/10.1899/07-062.1

Çabuk Y, Arslan N, Yılmaz V (2004) Species composition and seasonal variations of the Gastropoda in Upper Sakarya River System (Turkey) in relation to water quality. CLEANSoil, Air. Water (Basel) 32: 393-400. https://doi.org/10.1002/aheh.200300544

Carlsson NO, Brönmark C, Hansson LA (2004) Invading herbivory: The golden apple snail alters ecosystem functioning in Asian wetlands. Ecology 85(6): 1575-1580. https://doi. org/10.1890/03-3146

Cloherty TM, Rachlin JW (2011) Physicochemical and shoreline development factors affecting lake littoral benthic macroinvertebrates. Journal of Freshwater Ecology 26: 517-525. https://doi.org/10.1080/02705060.2011.588435

Conde-Padin P, Carvajal-Rodriguez A, Carballo M, Caballero A, Rolán-Alvarez E (2007a) Genetic variation for shell traits in a direct-developing marine snail involved in a putative sympatric ecological speciation process. Evolutionary Ecology 21(5): 635-650. https://doi. org/10.1007/s10682-006-9142-8

Conde-Padin P, Grahame JW, Rolán-Alvarez E (2007b) Detecting shape differences in species of the Littorina saxatilis complex by morphometric analysis. The Journal of Molluscan Studies 73(2): 147-154. https://doi.org/10.1093/mollus/eym009

Council Directive (1992) 92/43/EEC of 21 May 1992 on the conservation of natural habitats and of wild fauna and flora. Official Journal of the European Union 206: 7-50. http://eurlex.europa.eu/legal-content/EN/TXT/PDF/?uri=CELEX:31992L0043\&from=EN

Covich AP (2010) Winning the biodiversity arms race among freshwater gastropods: Competition and coexistence through shell variability and predator avoidance. Hydrobiologia 653(1): 191-215. https://doi.org/10.1007/s10750-010-0354-0

Danielidis DB, Spartinou M, Economou-Amilli A (1996) Limnological survey of Lake Amvrakia, western Greece. Hydrobiologia 318(3): 207-218. https://doi.org/10.1007/BF00016682

Davis GM, Kitikoon V, Temcharoen P (1976) Monograph on "Lithoglyphopsis" aperta, the snail host of Mekong River schistosomiasis. Malacologia 15: 241-287.

Davis GM, Guo YH, Hoagland KE, Chen PL, Zheng LC, Yang HM, Chen DJ, Zhou YF (1986) Anatomy and Systematics of Triculini (Prosobranchia: Pomatiopsidae: Triculinae), Freshwater Snails from Yunnan, China, with Descriptions of New Species. Proceedings of the Academy of Natural Sciences of Philadelphia Natural Sciences of Philadelphia 138: 466-575. http://www.jstor.org/stable/4064917 
Dimitriou E, Zacharias I (2006) Quantifying the rainfall-water level fluctuation process in a geologically complex lake catchment. Environmental Monitoring and Assessment 119(1-3): 491-506. https://doi.org/10.1007/s10661-005-9039-y

Downing JA, Van Meter P, Woolnough DA (2010) Suspects and evidence: A review of the causes of extirpation and decline in freshwater mussels. Animal Biodiversity and Conservation 33: 151-185. http://www.raco.cat/index.php/ABC/article/view/214978/285495

Dudgeon D, Arthington AH, Gessner MO, Kawabata ZI, Knowler DJ, Lévêque C, Naiman RJ, Prieur-Richard AH, Soto D, Stiassny MLJ, Sullivan CA (2006) Freshwater biodiversity: Importance, threats, status and conservation challenges. Biological Reviews of the Cambridge Philosophical Society 81(02): 163-182. https://doi.org/10.1017/S1464793105006950

Falniowski A (1987) Hydrobioidea of Poland (Prosobranchia: Gastropoda). Folia Malacologica 1: 1-119. https://doi.org/10.12657/folmal.001.001

Glöer P, Albrecht C, Wilke T (2007) Enigmatic distribution patterns of the Bithyniidae in the Balkan Region (Gastropoda: Rissooidea). Mollusca 25: 13-22. http://www.malaco.de/ Sonderdrucke/03_Gloeer_Albrecht_Wilke.pdf

Giokas S, Páll-Gergely B, Mettouris O (2014) Nonrandom variation of morphological traits across environmental gradients in a land snail. Evolutionary Ecology 28(2): 323-340. https://doi.org/10.1007/s10682-013-9676-5

Griffith HI, Kryštufek B, Reed JM (2004) Balkan biodiversity: pattern and process in the European hotspot. Kluwer Academic Publishers, Dordrecht, 1-358. https://doi. org/10.1007/978-1-4020-2854-0

Haase M, Misof B (2009) Dynamic gastropods: Stable shell polymorphism despite gene flow in the land snail Arianta arbustorum. Journal of Zoological Systematics and Evolutionary Research 47(2): 105-114. https://doi.org/10.1111/j.1439-0469.2008.00488.x

Hayes DM, Minton RL, Perez KE (2007) Elimia comalensis (Gastropoda: Pleuroceridae) from the Edwards Plateau, Texas: Multiple unrecognized endemics or native exotic? American Midland Naturalist 158(1): 97-112. http://www.jstor.org/stable/4500639. https://doi. org/10.1674/0003-0031(2007)158[97:ECGPFT]2.0.CO;2

Hershler R, Ponder WF (1998) A review of morphological characters of hydrobioid snails. Smithsonian Contributions to Zoology 600(600): 1-55. https://doi.org/10.5479/si.00810282.600

Howard JK, Klausmeyer KR, Fesenmyer KA, Furnish J, Gardali T, Grantham T, Katz JVE, Kupferberg S, McIntyre P, Moyle PB, Ode PR, Peek R, Quiñones RM, Rehn AC, Santos N, Schoenig S, Serpa L, Shedd JD, Slusark J, Viers JH, Wright A, Morrison SA (2015) Patterns of Freshwater Species Richness, Endemism, and Vulnerability in California. PLoS One 10(7): e0130710. https://doi.org/10.1371/journal.pone.0130710

Kazibwe F, Makanga B, Rubaire-Akiiki C, Ouma J, Kariuki C, Kabatereine NB, Booth M, Vennervald BJ, Sturrock RF, Stothard JR (2006) Ecology of Biomphalaria (Gastropoda: Planorbidae) in Lake Albert, Western Uganda: snail distributions, infection with schistosomes and temporal associations with environmental dynamics. Hydrobiologia 568(1): 433-444. https://doi.org/10.1007/s10750-006-0224-y

Klingenberg CP (2011) MorphoJ: An integrated software package for geometric morphometrics. Molecular Ecology Resources 11(2): 353-357. https://doi.org/10.1111/j.17550998.2010.02924.x 
Kobelt W (1878) Diagnosen neuer Arten. Jahrbuch der Deutschen Malakozoologischen Gesellschaft 5: 319-321.

Lodge DM, Brown KM, Klosiewski SP, Stein RA, Covich AP, Leathers BK, Brönmark C (1987) Distribution of freshwater snails: Spatial scale and the relative importance of physicochemical and biotic factors. American Malacological Bulletin 5: 73-84.

Nilsson E, Olsson K, Persson A, Nyström P, Svensson G, Nilsson U (2008) Effects of stream predator richness on the prey community and ecosystem attributes. Oecologia 157(4): 641-651. https://doi.org/10.1007/s00442-008-1097-8

Økland J (1983) Factors regulating the distribution of freshwater snails (Gastropoda) in Norway. Malacologia 24: 277-288.

Overbeck J, Anagnostidis K, Economou-Amilli A (1982) A limnological survey of three Greek lakes: Trichonis, Lyssimachia and Amvrakia. Archiv für Hydrobiologie 95: 365-394.

Páll-Gergely B, Kornilios P, Giokas S (2012) Higher than anticipated diversity within an Albinaria species (Gastropoda, Pulmonata, Clausiliidae) in Southern Turkey. Journal of Biological Research (Thessaloniki) 18: 345-352.

Pérez-Quintero JC (2012) Environmental determinants of freshwater mollusc biodiversity and identification of priority areas for conservation in Mediterranean water courses. Biodiversity and Conservation 21(12): 3001-3016. https://doi.org/10.1007/s10531-012-0351-x

Pfenninger M, Magnin F (2001) Phenotypic evolution and hidden speciation in Candidula unifasciata ssp (Helicellinae, Gastropoda) inferred by $16 \mathrm{~S}$ variation and quantitative shell traits. Molecular Ecology 10(10): 2541-2554. https://doi.org/10.1046/j.0962-1083.2001.01389.x Pilotto F, Free G, Cardoso AC, Wolfram G, Solimini AG (2012) Spatial variance of profundal and sublittoral invertebrate benthic communities in response to eutrophication and morphological pressures. Fundamental and Applied Limnology. Archiv für Hydrobiologie 180(2): 101-110. https://doi.org/10.1127/1863-9135/2012/0206

Pip E (1986) The ecology of freshwater gastropods in the central Canadian region. The Nautilus 100: 56-66.

Poulimenos G, Doutsos T (1997) Flexural uplift of rift flanks in central Greece. Tectonics 16(6): 912-923. https://doi.org/10.1029/97TC01658

Pyron M, Brown KM (2015) Introduction to mollusca and the class Gastropoda. In: Thorp JH, Rogers DC (Eds) Covich's Freshwater Invertebrates: Ecology and General Biology. Elsevier, 383-421. https://doi.org/10.1016/B978-0-12-385026-3.00018-8</edb>

Radea C, Louvrou I, Economou-Amilli A (2008) First record of the New Zealand mud snail Potamopyrgus antipodarum JE Gray 1843 (Mollusca: Hydrobiidae) in Greece - Notes on its population structure and associated microalgae. Aquatic Invasions 3(3): 341-344. https:// doi.org/10.3391/ai.2008.3.3.10

Radoman P (1973) On the relations of some freshwater Mollusca of the Balkan Peninsula and Asia Minor. Basteria 37: 77-84. http://natuurtijdschriften.nl/download?type=document;docid=596599

Radoman P (1983) Hydrobioidea a superfamily of Prosobranchia (Gastropoda) 1. Systematics. Monographs 547/57. Srpska Akademija Nauka i Umetnosti Posebna Izdanja, 1-256.

Régnier C, Fonatine B, Bouchet P (2009) Not knowing, not recording, not listing: Numerous unnoticed mollusc extinctions. Conservation Biology 23(5): 1214-1221. https://doi. org/10.1111/j.1523-1739.2009.01245.x 
Reischütz A, Reischütz PL (2002) Helleniká pantoía, 2: Limni Amvrakia - vom raschen Sterben eines Langzeitsees (Aitolien/Akarnanien, Griechenland). Nachrichtenblatt der Ersten Vorarlberger Malakologischen Gesellschaft 10: 59-60. https:/www.zobodat.at/pdf/NachErstMalaGes_10_0059-0060.pdf

Reischütz A, Reischütz PL, Fischer W (2008) Helleniká pantoía, 17: Zur Kenntnis der Molluskenfauna des Acheloos (Aitolien/Akarnanien, Griechenland). Nachrichtenblatt der Ersten Vorarlberger Malakologischen Gesellschaft 15: 17-20. http://ipp.boku.ac.at/private/ wf/Publikationen/N_15_17-20.pdf

Riedel F, Healy JM, Röpstorf P, Sitnikova TY (2001) Ecology, shell morphology, anatomy and sperm ultrastructure of the caenogastropod Pyrgula annulata, with a discussion of the relationship between the 'Pyrgulidae' and Caspian and Baikalian rissooideans. Limnologica 31(4): 289-302. https://doi.org/10.1016/S0075-9511(01)80031-1

Rohlf FJ (2006) tpsDig, Digitize landmarks and outlines, version 2.0. Department of Ecology and Evolution, State University of New York at Stony Brook.

Rohlf FJ, Marcus LF (1993) A revolution in morphometrics. Trends in Ecology \& Evolution 8(4): 129-132. https://doi.org/10.1016/0169-5347(93)90024-J

Schreiber ESG, Quinn GP, Lake PS (2003) Distribution of an alien aquatic snail in relation to flow variability, human activities and water quality. Freshwater Biology 48(6): 951-961. https://doi.org/10.1046/j.1365-2427.2003.01070.x

Schreiber K, Hauffe T, Albrecht C, Wilke T (2012) The role of barriers and gradients in differentiation processes of pyrgulinid microgastropods of Lake Ohrid. Hydrobiologia 682(1): 61-73. https://doi.org/10.1007/s10750-011-0864-4

Schütt H (1962) Neue Süsswasser-Prosobranchier Griechenlands. Archiv für Molluskenkunde 91: $157-166$.

Strayer DL, Dudgeon D (2010) Freshwater biodiversity conservation: Recent progress and future challenges. Journal of the North American Benthological Society 29(1): 344-358. https://doi.org/10.1899/08-171.1

Szarowska M (2006) Molecular phylogeny, systematics and morphological character evolution in the Balkan Rissooidea (Caenogastropoda). Folia Malacologica 14(3): 99-168. https:// doi.org/10.12657/folmal.014.014

Szarowska M, Falniowski A, Riedel F, Wilke T (2005) Phylogenetic relationships of the subfamily Pyrgulinae (Gastropoda: Caenogastropoda: Hydrobiidae) with emphasis on the genus Dianella Gude, 1913. Zootaxa 891(1): 1-32. https://doi.org/10.11646/ zootaxa.891.1.1

Ter Braak CJF, Šmilauer P (1998) CANOCO Reference manual and User's Guide to CANOCO for Windows. Software for Canonical Community Ordination (version 4). Centre for Biometry, Wageningen, 1-352.

Thomatou AA, Zacharias I, Hela D, Konstantinou I (2013a) Determination and risk assessment of pesticide residues in lake Amvrakia (W. Greece) after agricultural land use changes in the lake's drainage basin. International Journal of Environmental Analytical Chemistry 93(7): 780-799. https://doi.org/10.1080/03067319.2012.656099

Thomatou AA, Triantafyllidou M, Chalkia E, Kehayias G, Konstantinou I, Zacharias I (2013b) Land Use Changes Do Not Rapidly Change the Trophic State of a Deep Lake. Amvrakia 
Lake, Greece. Journal of Environmental Protection 4(05): 426-434. https://doi.org/10.4236/ jep.2013.45051

Verginis S, Leontaris S (1978) Beiträge zur Morphologie und Entwicklung des Semipoljes Amvrakia (Limni Amvrakia), West-Griecheland. Internationale Revue der Gesamten Hydrobiologie und Hydrographie 63: 831-839. https://doi.org/10.1002/iroh.19780630615

Wilke T, Albrecht C, Anistratenko VV, Sahin SK, Yıldırım MZ (2007) Testing biogeographical hypotheses in space and time: Faunal relationships of the putative ancient Lake Eğirdir in Asia Minor. Journal of Biogeography 34(10): 1807-1821. https://doi.org/10.1111/j.13652699.2007.01727.x

Wilke T, Haase M, Hershler R, Liu HP, Misof B, Ponder W (2013) Pushing short DNA fragments to the limit: Phylogenetic relationships of 'hydrobioid' gastropods (Caenogastropoda: Rissooidea). Molecular Phylogenetics and Evolution 66(3): 715-766. https://doi. org/10.1016/j.ympev.2012.10.025

Zacharias I, Bertachas I, Skoulikidis N, Koussouris T (2002) Greek lakes: Limnological overview. Lakes and Reservoirs: Research and Management 7(1): 55-62. https://doi. org/10.1046/j.1440-1770.2002.00171.x

Zelditch ML, Swiderski DL, Sheets HD, Fink WL (2004) Geometric morphometrics for biologists. A Primer. Elsevier Academic Press, Amsterdam, 1-488.

Zohary T, Ostrovsky I (2011) Ecological impacts of excessive water level fluctuations in stratified freshwater lakes. Inland Waters 1(1): 47-59. https://doi.org/10.5268/IW-1.1.406

Zukowski S, Walker KF (2009) Freshwater snails in competition: Alien Physa acuta (Physidae) and native Glyptophysa gibbosa (Planorbidae) in the River Murray, South Australia. Marine \& Freshwater Research 60(10): 999-1005. https://doi.org/10.1071/MF08183 